\title{
Reviews
}

\section{CD44 and the adhesion of neoplastic cells}

\author{
Zbigniew Rudzki, Serge Jothy
}

\begin{abstract}
CD44 is a family of transmembrane glycoproteins that act mainly as a receptor for hyaluronan. It can also bind some other extracellular matrix ligands (chondroitin sulphate, heparan sulphate, fibronectin, serglycin, osteopontin) with lower
\end{abstract} affinity. CD44 is encoded by a single gene containing 20 exons, 10 of which (v1-v10) are variant exons inserted by alternative splicing. The standard, ubiquitously expressed isoform of CD44, does not contain sequences encoded by these variant exons. Numerous variant isoforms of CD44 containing different combinations of exons v1-v10 inserted into the extracellular domain can be expressed in proliferating epithelial cells and activated lymphocytes. CD44 plays a significant role in lymphocyte homing. Both alternative splicing and glycosylation influence receptor function of the molecule, usually reducing its affinity to hyaluronan. The cytoplasmic domain of CD44 communicates with the cytoskeleton via ankyrin and proteins belonging to the ezrin-moesin-radixin family. Relatively little is known about the intracellular events following interactions of CD44 with its ligands. Some variant isoforms, especially those containing sequences encoded by v6-v10, are overexpressed in both human and animal neoplasms. In a rat pancreatic adenocarcinoma model one of the variant CD44 isoforms was proved to be determinant in the metastatic process. For some human neoplasms (carcinomas of the digestive tract, non-Hodgkin's lymphomas, thyroid carcinomas, and others) correlations have been made between the particular pattern of CD44 variants produced by neoplastic cells and clinicopathological parameters of tumours, such as grade, stage, presence of metastases, and survival. In vitro studies indicate that modifications of CD44 expression result in different ligand recognition and influence cell motility, invasive properties, and metastatic potential of experimental tumours. Investigation of CD44 neoexpression can be useful both in early cancer diagnosis and in predicting tumour behaviour. It can also contribute to better understanding of molecular mechanisms leading to neoplastic transformation.

(F Clin Pathol: Mol Pathol 1997;50:57-71)

Keywords: CD44; cell adhesion; cancer

One of the important basic features of tumour cell biology is the property of malignant cells to change their adhesion to other cells and to the extracellular matrix. This property lends the cancer cells the potential to detach from their original site of tumour growth and to invade surrounding tissues. CD44 is a typical example of a cell adhesion protein which undergoes dramatic structural and functional changes during malignant transformation.

\section{Terminology}

CD44 is a family of glycoprotein molecules, which received its name during the Third International Workshop on Leukocyte Differentiation Antigens. ${ }^{1}$ This nondescriptive term has replaced names used previously, including: lymphocyte homing receptor (gp90 Hermes), phagocytic glycoprotein (Pgp-1), extracellular matrix receptor III (ECMRIII), and hyaluronate receptors (H-CAM) and HUTCH-1. CD44 was described first in the early 1980s, based on the reactivity of an antibody called $F$ 10.44.2..$^{2-4}$ Because the separately described and named molecules with diverse functions were found to be the product of one gene, the interest in CD44 increased rapidly, resulting in over 800 publications in the past five years.

\section{Genomic organisation and protein} structure

CD44 is the product of a single gene, located on the short arm of human chromosome $11 .{ }^{5}$ Genomic DNA studies have documented that CD44 is encoded by at least 20 exons. The first five (s1-s5) as well as exons 16 to 20 (s6-s10) are almost invariably expressed by a large number of non-epithelial cells, including those which are haematopoietic; their product is referred to as the "standard" or "haematopoietic" form of CD44 (abbreviated to CD44s or $\mathrm{CD} 44 \mathrm{H}) .^{6}$ Exons 6 to 15 , more often called v1-v10, are alternatively spliced. ${ }^{7}$ Despite their name, some "standard" exons can occasionally participate in alternative splicing, and some of the variant ones contain "cryptic" splice sites. The structure of CD44 is illustrated in figure 1. 


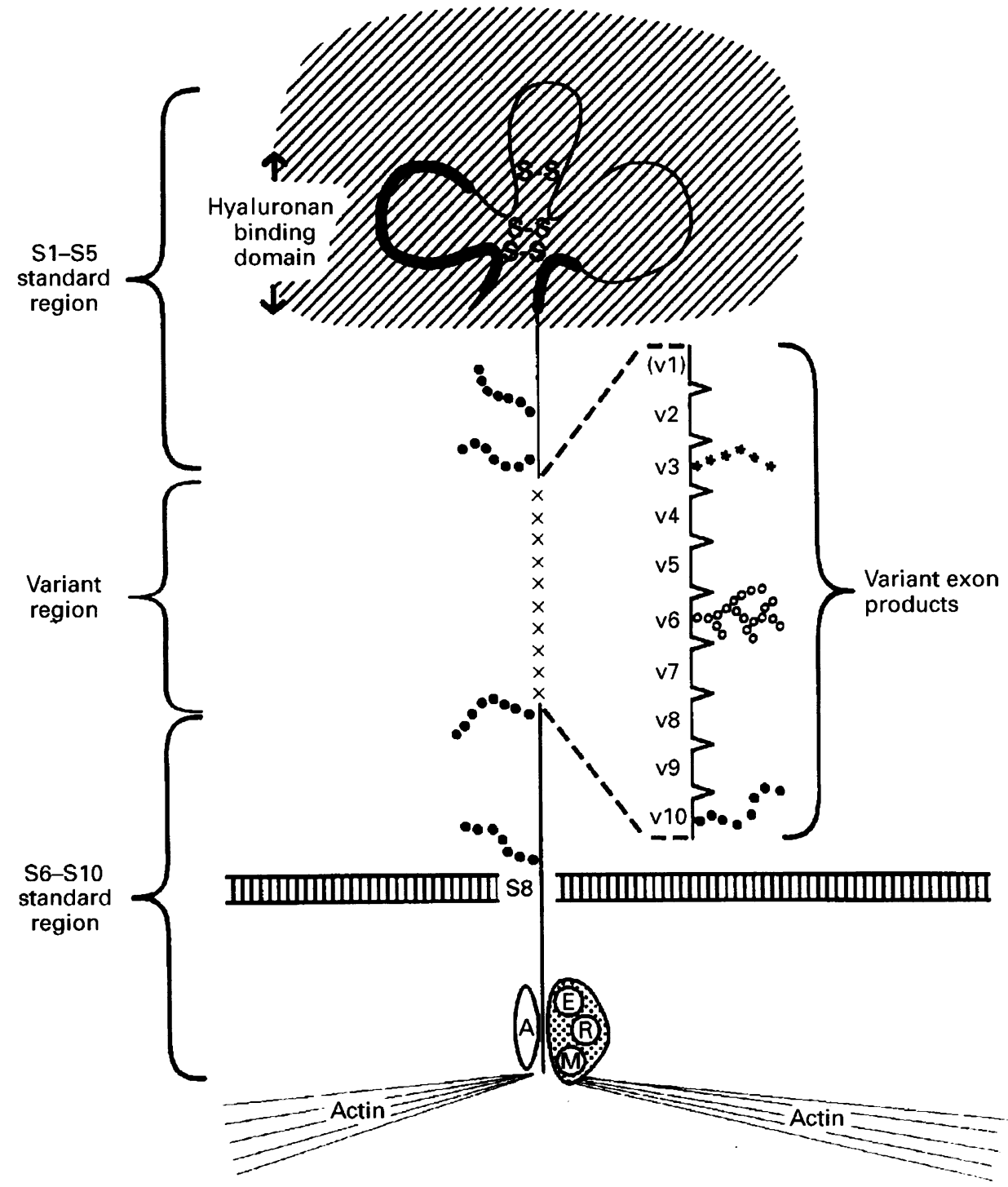

Figure 1 CD44 structure. Bold regions in the distal extracellular domain identify the hyaluronan binding sequences. Sequences from up to 10 alternatively spliced exons $(v 1-v 10)$ can be inserted in the proximal extracellular domain. In humans the $v 1$ exon contains a stop codon and is not expressed. The cytoplasmic domain interacts with the actin filaments through ankyrin $(A)$ or members of the ERM (ezrin-radixin-moesin) family. Closed circles, chondroitin sulphate; asterisks, heparan sulphate; open circles, blood group $H$ antigen.

Unlike the mouse CD44 gene, the human exon v1 contains a stop codon at the 17 th amino acid residue and probably does not give rise to a protein product. ${ }^{8}$ There is no evidence that human CD44 isoforms contain the vl sequence. Human genomic vl was discovered only after finding the homologous murine exon, therefore, it is sometimes designated as exon $5 \mathrm{a}$ or $6 \mathrm{a}$, and subsequent exons receive the numbers from 6 to 19 or from 7 to 20, which can lead to some terminological confusion. ${ }^{9}$ Similarly, there is no widely accepted terminology for the large number of resulting isoforms described, the only exception being that containing the product of exons v8-v10, known as an "epithelial" variant (CD44E). However, even this isoform (CD44v48-10) has been called "CD44R1" by another group. ${ }^{10}$ The largest human isoform, containing the insert encoded by all alternatively spliced exons from v2 to v10 was called "epican". ${ }^{1}$ The number of isoforms docu- mented so far approaches 100 ; theoretically there could be more than 1000 combinations.

The standard form of human CD44 is composed of 361 amino acids $(37-42 \mathrm{kDa}){ }^{6}$ In humans the largest insert, resulting from alternative splicing, contains an additional 381 amino acids. The CD44 molecule can be subdivided into four distinct regions. ${ }^{12}$ The $\mathrm{N}$ terminal found in the extracellular domain is encoded by exons s1-s5 and is highly conserved among the species. ${ }^{13}$ Three pairs of cysteine residues forming disulphide bonds shape the CD44 ectodomain into globular loops. Two chondroitin sulphate chains can be attached to the product of exon s5. The $\mathrm{N}$ terminal region shares a limited (approximately $30 \%$ ) sequence homology with the B-loop of the cartilage link protein and other extracellular hyaladherins, such as aggrecan and versican. The $\mathrm{N}$ terminal region of CD44 contains two binding sites for hyaluronic acid, also called hyaluronan, within regions correspond- 
ing to exons $s 2$ and $s 5$. These hyaluronan binding motifs, called "B(X7)B", consist of seven amino acids, none of them acidic, flanked by two basic amino acids-either arginine or lysine. ${ }^{14}$ One of them, located closer to the $\mathrm{N}$ terminus, lies within the region homologous with the cartilage link protein and contains arginine at position 41 , which is necessary for hyaluronan recognition. ${ }^{15}$ The second more proximal region located in a domain with no significant homology with other hyaladherins seems to play an accessory role. ${ }^{15}$ Recently, a third hyaluronan binding $\mathrm{B}(\mathrm{X} 7) \mathrm{B}$ motif was described, partially overlapping that previously identified within exon s5 product. ${ }^{16}$ Similar hyaluronan recognition sequences have been identified in another cell surface hyaluronan receptor-RHAMM (receptor for hyaluronan mediated motility). ${ }^{14}$ The membrane proximal domain, encoded by exons s6 and s7, is less well conserved among the species (approximately $50 \%$ ) and contains the site for insertion of the alternative splicing products between s5 and s6. Up to 381 amino acids, encoded by various combinations of alternatively spliced exons v1-v10 can be added at amino acid 223 . These alternatively spliced exons do not show any significant homology with any other protein sequences and their function remains largely unknown. The limited similarity between the alternatively spliced exons themselves suggests that they might have evolved from a common ancestor sequence by means of duplication. ${ }^{8}$ At least three of them have potential binding sites for heparan sulphate and chondroitin sulphate through the SGXG motif found within the product of exon v3. ${ }^{17}$ Fucose rich $\mathrm{H}$ blood group antigens can also bind to v6, and v10 contains two potential binding sites for chondroitin sulphate. ${ }^{18}$ The proximal extracellular region, encoded by standard exons is also a target of posttranslational modifications, binding up to three chains of chondroitin-4-sulphate.

The short hydrophobic transmembrane domain composed of 23 amino acids is encoded by exon $\mathrm{s} 8$, the remaining three amino acids of this exon coding for the beginning of the cytoplasmic tail. ${ }^{6}$ Exons $s 9$ and $s 10$, despite their names, can also be alternatively spliced, resulting in the short-tail (additional three amino acids, exon s9) or much more prevalent, longtail (additional 67 amino acids, exon s10) version of the cytoplasmic domain..$^{19}$ It is unclear, whether the short-tail form of CD44 is expressed on the cell surface, and if it has any functional role. Four serine residues in the cytoplasmic domain are potential substrates for various kinases and there is a limited homology between this part of CD44 and sequences found in the $G$ protein family. ${ }^{20}$

The sequence between amino acids 305 and 355 of the CD44 cytoplasmic domain contains two putative ankyrin binding sites. ${ }^{21}$ The molecular mass of the mature protein usually exceeds $85 \mathrm{kDa}$, as numerous potential $\mathrm{N}$ and $O$ glycosylation sites of the extracellular domains are substituted by carbohydrates. Potential $\mathrm{O}$ glycosylation sites, distinguished by high serine/threonine content, are especially abundant within the products of alternatively spliced exons, v10 containing the largest number of serine/threonine rich regions. ${ }^{22}$ The chondroitin and heparan sulphate chains also contribute to the final molecular mass of some CD44 species, the former increasing it approximately by an additional $110-120 \mathrm{kDa}{ }^{23}$ Thus the most prevalent form of CD44 (CD44s) is typically encountered as the $85-95 \mathrm{kDa}$ "backbone" or as a $190 \mathrm{kDa}$ variant, both carrying the chondroitin sulphate chains. The suggestion that the heavier variant represents the disulphide linked homodimer of the former has not been confirmed. ${ }^{24}$

The CD44 protein has been described in human, mouse, rat, hamster, goat, pig, dog, sheep, cattle, and horse, with the $\mathrm{N}$ terminal and cytoplasmic domains showing the closest sequence homology (80-90\%) among species. ${ }^{4}$ The variant region (v1-v10) is similarly well conserved between mouse and rat sequences; the human-rodent homology of this region is approximately $65 \% .^{8}$ Interestingly, most of the $\mathrm{O}$ glycosylation sites, as well as the substitution sites for chondroitin sulphate chains, belong to the well conserved regions, whereas this is not always the case for the targets for $\mathrm{N}$ glycosylation. ${ }^{8}$ A strikingly high interspecies homology characterises the intronic sequences, especially the intron v4-v5 (68\% between human and mouse). Introns are usually poorly conserved, therefore, their evolutionary preservation in the CD44 variant region suggests the possible role of intron encoded information in splicing regulation. So far no CD44 or CD44like protein has been described in organisms other than mammals.

\section{Expression of CD44 in various tissues}

If regarded as a family of molecules, CD44 is a ubiquitous cell protein. Recently, a panel of monoclonal antibodies directed against the standard isoform of CD44, as well as the products of variant exons, was used to examine both adult and embryonal human tissues. ${ }^{25}{ }^{26}$ Generally, most epithelial and non-epithelial tissues expressed CD44s, whereas positive reactions with antibodies against exon v6, v9, and v4 were far more restricted. The following adult tissues had no detectable expression of standard or variant CD44: ependyma, epithelium of the choroid plexus, surface epithelium of stomach and intestine, hepatocytes, endocrine portion of pancreas, pancreatic acinar cells, adrenal glands, kidney proximal tubules and collecting ducts as well as Bowman's capsule, ovarian germinal epithelium, testicular germ cells, striated muscle (both cardiac and skeletal), Sertoli cells, and astrocytes. The standard form of CD44 is probably the only one encountered in non-epithelial tissues, except for microglia that show weak reaction to anti-v6 antibodies. ${ }^{25}$

Epithelial tissues differ markedly with regards to the expression of variant isoforms, but generally the products of exon v9 parallel the occurrence of CD44s. In normal breast, the "epithelial" form of CD44 (CD44E) seems to be even more abundant than the standard one, at least at the mRNA level. ${ }^{27}$ Breast duct 
myoepithelium differs from the epithelial layer by the display of $\mathrm{v} 6$ containing CD44 isoforms. $^{25}$ v6 containing isoforms are more restricted and are found mainly in squamous and transitional epithelia and ductal parts of glands, the pancreas being a typical example. ${ }^{28}{ }^{29}$ Oesophageal epithelium, basal and lower intermediate urothelium as well as the lower layers of epidermis belong to the very rare localisations of $\mathrm{v} 4$ containing isoforms. ${ }^{25}{ }^{30}$ One of them is epican ( $\mathrm{v} 2-\mathrm{v} 10$ ), expressed in the epidermis from the basal to the granular cell layer. ${ }^{11}$ Generally, in epithelial tissues the variant isoforms tend to be more strongly expressed in proliferating cells. ${ }^{26}$ CD44 expression in fetal tissues is usually similar but less prominent than in adult counterparts. A notable exception is embryonal skeletal muscle, which is strongly positive for CD $44 \mathrm{~s}^{25}$ Isoforms containing v1 encoded sequences have not been identified in human tissue, probably because human vl contains the stop codon. ${ }^{8}$ In mice this exon is not interrupted by the stop signal; however, expression of murine isoforms containing $\mathrm{v} 1$ is highly restricted and has been found only in the stomach. In polarised epithelial cells, CD44 occupies mainly the lateral plasma membranes. The cytoplasmic domain is responsible for this restricted localisation, as mutants lacking the $\mathrm{C}$ terminal tail are distributed instead on the apical part of the cells. ${ }^{31}$ In fibroblasts CD44 preferentially occupies the cytoplasmic projections and this localisation requires the integrity of its intracellular domain. ${ }^{32}$ Almost all cells of connective tissue, such as fibroblasts, endothelial cells, and macrophages contain large amounts of CD44s. Hence there is no CD44 free organ or cellular microenvironment in the human body. Haemopoietic cells are characterised by a high expression of CD44; their membrane contains $10^{4}-10^{5}$ molecules, mainly of the standard type $^{33}$; however, more than one CD44 isoform can be expressed by a single cell. ${ }^{34}$

Soluble CD44 $(5 \mu \mathrm{g} / \mathrm{ml})$ can be detected in human serum. ${ }^{35}$ It is probably released from the cell surfaces by proteolytic enzymes but its biological significance as well as the exact cell of origin is unknown. Interestingly, in patients with gastric and colonic carcinoma, the serum concentration acts as a marker of a neoplastic process, as values are increased nearly 10 -fold and correlate positively with tumour burden. ${ }^{36}$

\section{Physiological functions of CD44}

CD44 AS A HYALURONAN BINDING GLYCOPROTEIN Hyaluronan is the main ligand of CD44. It is an abundant component of the extracellular matrix and consists of a linear polymer of repeated disaccharide units composed of D-glucuronic acid and $\mathrm{N}$-acetyl-D-glucosamine. It differs from other glycosaminoglycans by its lack of covalently linked peptide chains and a single extended molecule can reach a length of $10 \mu \mathrm{m}$ and a mass of up to $10000 \mathrm{kDa}$. A hydrated hyaluronan molecule can form a random coil of up to $500 \mathrm{~nm}$ in diameter. Aggregates composed of hyaluronan attached to proteoglycans by the $40 \mathrm{kDa}$ link protein perform important mechanical func- tions in various tissues, contributing to physical resistance. They also act as an osmotic buffer and a filter regulating the diffusion of macromolecules.

Hyaluronan binding properties of what was called "fibroblast surface protein", later found to be identical to CD44, were first reported in the 1980s. ${ }^{37-39}$ CD44 mediates the adhesion of stromal cells to the lymphoid precursors in bone marrow. ${ }^{40}$ This interaction is blocked by both hyaluronidase and anti-CD44 antibodies, and is optimal at neutral pH. Some anti-CD44 antibodies potentiate ligand recognition, as illustrated by the IRAWB14 monoclonal antibody, which recognises an epitope situated between hyaluronan binding motifs. ${ }^{41}$ Most binding assays have been performed in the presence of divalent cations. However, CD44 mediated adhesion can occur in the absence of calcium, with both of its known ligands: hyaluronan and osteopontin. ${ }^{40}{ }^{42-44}$ However, the binding affinity is relatively weak compared with the forces resulting from mechanisms involving cadherins or integrins. CD44hyaluronan interactions are approximately five times stronger then those mediated by RHAMM, the second widespread hyaluronan receptor. ${ }^{945}$

The $\mathrm{B}(\mathrm{X} 7) \mathrm{B}$ motifs, located on the CD44 extracellular domain are essential, but not sufficient for optimal hyaluronan binding. It is also uncertain which CD44 isoform is involved, its post-translational modifications, and cellular context. The standard form of CD 44 binds hyaluronan, whereas the ligand affinity of some variant isoforms, especially the "epithelial" one (CD44E) is much lower. ${ }^{24}{ }^{46}$ It is presently unclear, why the insertion of the additional amino acids encoded by variant exons in a location remote from the hyaluronan binding sites affects the CD44-hyaluronan interaction. An important issue is to define the role played by variant CD44 isoforms in the attachment to hyaluronan. Studies addressing this issue have led to different conclusions - for example, the murine homologue of human CD44E and other heavier murine isoforms do bind to the ligand when transfected into the AKR1 lymphoma cells. ${ }^{47}$ In addition, the CD44R1 isoform, when expressed in COS7 (SV40 transformed simian fibroblastoid cell line) or TIL1 (murine lymphoma) cells can bind hyaluronan. ${ }^{48}$ The CD44R1 isoform was regarded as similar but not identical to CD44E, but recently it was acknowledged that the amino acid composition of these two CD44 variants is the same (A Aruffo; personal communication). Whatever variant exon is spliced in CD44 transcripts, post-transcriptional modifications can still account for further changes in hyaluronan binding.

Various sugar moieties carried by CD44 modify its capacity to bind hyaluronan, probably by altering the folding or charge of the receptor molecule. O-glycosylation and to a lesser extent $\mathrm{N}$-glycosylation of the standard form of CD44 are necessary for transfected murine $\mathrm{T}$ lymphoma cells to bind to hyaluronan. ${ }^{50}$ Interestingly, glycosylation of some of the variant domains of CD44 has the 
opposite effect. ${ }^{22}$ Thus variable glycosylation of the CD44 molecule, particularly its "epithelial" variant, can serve as a mechanism regulating lectin function of this glycoprotein parallel to alternative splicing. Similarly, the attachment of chondroitin sulphate or heparan sulphate, both negatively charged molecules, to the v3 encoded region of CD44 can have an adverse effect on hyaluronan binding. ${ }^{17}$

Binding of CD44 positive cells to hyaluronan and their tumorigenesis potential also depend on whether CD44 remains attached to the plasma membrane or is shed in the extracellular space. ${ }^{51}$ Variant CD44 isoforms containing sequences encoded by v7-v10 shed quite easily into the extracellular space, probably as a result of proteolytic cleavage of CD44 at the junction between the transmembrane and cytoplasmic domains. The released fragments block CD44 dependent tumour formation, which relies on adhesion of neoplastic cells to hyaluronan. In contrast, the standard CD44 isoform does not shed easily, promoting local tumour growth on subcutaneous injection into nude mice. Cells transfected with isoforms containing products of v3, which completely fail to bind hyaluronan and do not release CD44, are the most efficient in forming bone marrow metastases after intravenous injection. This leads to the suggestion that the extensive glycosylation of the v3 coded region has several corollaries: abrogation of hyaluronan binding, specific protection from proteolysis, and promotion of unique metastatic properties, possibly by trapping growth factors. ${ }^{51}$

The cytoplasmic domain is essential for binding to soluble or immobilised hyaluronan and for hyaluronan-CD44 mediated motility. This process involves clustering of CD44 molecules at the surface of the cell. ${ }^{52}$

Alterations in hyaluronan binding also relate to changes in the number of CD44 molecules expressed on the cell membrane. Activation of lymphocytes by phorbol esters increases the expression of the CD44 standard isoform and results in increased binding to hyaluronan. ${ }^{53}$

Finally, the affinity of CD44 for hyaluronan depends on the size of the ligand molecule. Hyaluronan has no constant molecular mass in vivo and, generally, the longer the polymer chain the stronger the CD44 affinity for it. The minimal hyaluronan chain recognised by CD44 is six sugar residues in length. ${ }^{9}$

Binding to hyaluronan is unlikely to be the only functional consequence of CD44 expression. It is conceivable that associated events are related to it, including hyaluronan degradation, cell motility, and intracellular signalling. $\mathrm{Hy}-$ aluronan is degraded mostly in lymph nodes and to a lesser extent in the liver, spleen, kidneys, and lungs. ${ }^{94}$ Transformed cells are also efficient in hyaluronan degradation. A series of breast cancer cell lines was shown to degrade hyaluronan into short oligosaccharide chains, and Hermes-1 antibody which recognises the $\mathrm{N}$ terminal region of the CD44 ectodomain, was shown to block this process. ${ }^{55}$ Moreover, in this study positive correlation was demonstrated between CD44 associated hy- aluronan degradation and the invasive potential of the cell lines.

Hyaluronan promotes cell locomotion and its accumulation accompanies processes such as wound healing, embryogenesis (neural crest cell migration, and migration of mesenchymal cells forming the cardiac septum), and angiogenesis. ${ }^{56}$ However, a determinant role for CD44 in these processes remains speculative. In the mouse embryo, CD44 (both the standard form as well as the heavier isoforms) co-localises with hyaluronan during the various stages of development. ${ }^{57}$ The only strong evidence supporting CD44 dependent cell migration promoted by hyaluronan comes from studies using neoplastic cells. ${ }^{46}$ With respect to intracellular signalling, experiments with murine $\mathrm{T}$ lymphoma cells stimulated by hyaluronan showed a rapid increase in intracytoplasmic calcium, which was accompanied by CD44 capping on the cell surface, and increased binding of the cells to immobilised i hyaluronan. As this response can be blocked with anti-CD44 antibodies, it is probable that CD44 can also serve as an "outside-in" signal transducer. ${ }^{58}$

INTERACTIONS OF CD44 WITH OTHER LIGANDS

To date, hyaluronan remains the only component to which CD44 binds specifically. Cell binding to collagen type I, laminin, and fibronectin are also CD44 dependent, but are weaker and rely on the presence of linked chondroitin sulphate chains. ${ }^{59}$ These interactions can also be mediated by CD44 isoforms containing products of variant exons, as some colonic carcinoma cell lines expressing CD44E show binding to type IV collagen and laminin that can be blocked by anti-CD44 antibodies. ${ }^{60}$ In addition, CD44 negative murine lymphoma cells TIL1 transduced with CD44R1 (an isoform containing the product of exon v10 with the chondroitin sulphate chain attachment site) undergo spontaneous homotypic aggregation, probably mediated by the mutual recognition of CD44R1 molecules and chondroitin sulphate chains. ${ }^{49}$

Recently, serglycin (the sulphated proteoglycan of leucocyte secretory granules) was identified as another ligand for CD44. Serglycin can be exocytosed and interacts with CD44 on cell membrane leading to activation of lymphocytes. Again, the binding to CD44 is dependent on the chondroitin sulphate chains carried by the serglycin molecule. ${ }^{61}$

Heparan sulphate, attached to the region encoded by exon v3, contributes to another function of CD44 heavy weight isoforms, that is the binding of growth factors, possibly presenting them at sites of inflammatory reactions. Heparin binding epithelial growth factor (HB-EGF) and basic fibroblast growth factor (b-FGF), which are determinants of angiogenesis, belong to those so far identified. ${ }^{62}$ According to a recent report, osteopontin, which is a ubiquitous extracellular matrix glycoprotein, may be another ligand for CD $44 .{ }^{44}$ Osteopontin was originally described as a protein involved in bone apatite crystal formation, but it is also produced by a number of epithelial 
cells, vascular smooth muscle cells, and lymphocytes. Osteopontin is involved in such diverse processes as suppression of nitric oxide synthesis and promotion of cancer cell migration. ${ }^{63}$ In addition, osteopontin is a ligand for integrins and participates in calcium dependent adhesion. ${ }^{64}{ }^{65}$ By contrast, CD44 mediated adhesion does not require divalent cations, it does not involve a Gly Arg Gly Asp Ser sequence, nor is the presence of intact chondroitin sulphate chains attached to osteopontin necessary. However, examination of human osteopontin amino acid composition ${ }^{66}$ showed that it contains at least two potential $\mathrm{B}(\mathrm{X} 7) \mathrm{B}$ hyaluronan binding motifs. Methodology used by Weber et al does not rule out the possibility that CD44 osteopontin binding is indirect and mediated by hyaluronan chains that can bridge osteopontin molecules with CD44. ${ }^{44}$ The thrombin cleavage site present in osteopontin is confined to one of those motifs. Osteopontin produced by tumour cells and peritumoural macrophages promotes neoplastic cell motility when cleaved by thrombin ${ }^{67}$; therefore, the issue of CD44hyaluronan-osteopontin interactions at the advancing tumour margin seems to be an interesting field for future research.

\section{CD44 MEDIATED LYMPHOCYTE HOMING}

Lymphocyte homing refers to a process in which migrating lymphoid cells recognise a specific ligand on the surface of high endothelial venules and extravasate to the Peyer's patches and lymph nodes in some organs. ${ }^{68}$ Lymphocytes and their precursors, similar to other cells of haematopoietic origin, express CD44 from the very early to late stages of their maturation. The degree of CD44 expression on $T$ lymphocytes also depends on their activation. Antigenic stimulation or interleukin-2 combined with anti-CD3 antibodies not only increase the overall amount of CD44 on the lymphocyte membrane but also induce variant isoforms. ${ }^{69}$ This reaction is maximal 24 hours after stimulation and is followed by blast transformation and DNA synthesis. Stimulated T cells expressing more CD44 adhere more avidly to human endothelium..$^{71}$ Both responses can be blocked by the Hermes- 3 antibody which recognises the membrane proximal CD44 domain. This antibody does not interfere with CD44 hyaluronan interactions. Earlier, the so called "Hermes antigen" (subsequently identified as CD44) was shown to be involved in the homing of peripheral blood lymphocytes.

Non-inflammatory lymphocyte recirculation probably does not depend exclusively on CD44, as CD44 negative lymphocytes isolated from anti-CD44 treated normal mice still show the ability to home to the lymphoid organs. However, during inflammatory reactions the extravasation of leucocytes lacking CD44 is impaired and they are incapable of generating a cutaneous delayed-type hypersensitivity response in non-lymphoid tissues.
CD44 DURING LYMPHOPOIESIS AND HAEMATOPOIESIS

The earliest population of thymocytes expresses CD44s. Anti-CD44 antibodies are effective in preventing the repopulation of thymus by $T$ cell precursors in mice. ${ }^{72}$ During the subsequent maturation, naive $T$ cells lose their CD44, which is then regained by memory $T$ lymphocytes. The latter cells express both standard and variant exon containing isoforms, whereas in the early precursor thymocytes, the v9 product can be found only on the thymic medullary cells. ${ }^{2573}$

Similarly, anti-CD44 antibodies can interfere with $B$ cell development and mature B cells can transiently upregulate CD44 variant isoforms, including those containing the sequence encoded by exon v6. ${ }^{69} 74$ Cells from the myeloid and erythroid lineages also show a high expression of CD44. The specific role played by CD44 relates to adhesive interactions between haematopoietic and stromal cells in the bone marrow. $^{74}$

\section{ASSOCIATIONS BETWEEN CD44 AND THE} CYTOSKELETON

Cell motility experiments have shown that CD44 is connected to the cytoskeleton. ${ }^{32}$ This connection is dynamic and differs in various regions of a moving cell; CD44-cytoskeleton association is stronger at the leading edge of the cell membrane than at the trailing one. The exact nature of interactions between CD44 and cytoskeleton proteins awaits further clarification. There is evidence that CD44 binds to ankyrin, which connects the submembranous part of the cell scaffolding with the actin filament meshwork. ${ }^{75}$ The ankyrin binding domain of the intracytoplasmic portion of the CD44 molecule contains at least two regions recognising the ligand with different affinity. The ankyrin binding domain is necessary for hyaluronan binding, suggesting that the intracellular and extracellular functions of CD44 are connected. ${ }^{21}$ The ability to bind hyaluronan requires that at least 14 amino acids of the intracytoplasmic domain be preserved or that CD44 molecules be dimerised via the disulphide bonds. ${ }^{77}$ In contrast, treatment of activated lymphoid cells with cytochalasin B does not affect their ability to bind hyaluronan, suggesting that the interaction of CD44 with actin filaments is not indispensable for recognition of this ligand. ${ }^{78}$

New information on the association of CD44 with cytoskeletal proteins was provided when experiments showed that CD44 colocalises with the members of ERM (ezrinradixin-moesin) family in hamster and mouse cells. ${ }^{79}$ These proteins are involved in plasma membrane-actin connections such as formation of microvillous projections, adherens junctions, ruffling membranes, and cleavage furrows. ${ }^{80}$ Both standard CD44 as well as v9-v10 containing isoforms associate with ERM proteins, the affinity of the heavier isoforms being substantially greater. ${ }^{79}$ The function of the postulated CD44-ERM complex is unclear, as is that of the role of ankyrin. 
Table 1 CD44 expression and relevance to tumour progression in various human cancers

\begin{tabular}{|c|c|c|}
\hline Human tumour (references) & CD44 species expression* & Relevance to tumour progression \\
\hline Pancreatic carcinoma ${ }^{28}$ & v6 & $?$ \\
\hline Non-Hodgkin's lymphoma ${ }^{89}$ & v3, v6, v9 & Identifies poor prognosis \\
\hline Melanoma $^{92}$ & v5 & Biologically more aggressive \\
\hline Colonic carcinoma 98106 & v5, v6 & $\begin{array}{l}\text { Correlates with malignant } \\
\text { transformation }\end{array}$ \\
\hline Gastric carcinoma $^{118120}$ & $\mathrm{v} 8-\mathrm{v} 10$ & Correlates with metastases \\
\hline $\begin{array}{l}\text { Thyroid carcinoma } \\
\text { (papillary-type) }\end{array}$ & v6 & $\begin{array}{l}\text { Correlates with lymph node } \\
\text { metastases }\end{array}$ \\
\hline Lung adenocarcinoma ${ }^{136}$ & Not investigated & $\begin{array}{l}\text { Loss of overall CD } 44 \\
\text { expression correlates with } \\
\text { poor prognosis }\end{array}$ \\
\hline Neuroblastoma $^{142}$ & Standard CD44 & $\begin{array}{l}\text { Loss of overall CD } 44 \\
\text { expression correlates with } \\
\text { poor prognosis }\end{array}$ \\
\hline
\end{tabular}

${ }^{\star} \mathrm{CD} 44$ isoforms are either undetectable in autologous normal cells from the same organ or are present at low concentration and markedly overexpressed in malignant tumours.

\section{CD44 involvement in neoplastic invasion and metastasis}

THE ORIGINAL DESCRIPTION OF CD44 AS A

“METASTASIS" MOLECULE

The participation of CD44 in tumour progression and metastases formation was first documented in an animal tumour model. This was established during a search for antigenic determinants discriminating between metastasising and non-metastasising subclones of a rat adenocarcinoma cell line. ${ }^{81}$ The generation of cDNA clones identified the metastasising cell specific protein as a variant of CD44 containing the product of exon v6. Further experiments confirmed that expression of this particular CD44 variant molecule in transfected non-metastasising cells confers the ability to form distant metastases. Furthermore, non-cytotoxic antibodies specific for this CD44 variant inhibited formation of secondary neoplastic foci when injected with tumour cells. ${ }^{82}$ Thus, in this particular system, a single molecule-CD44 carrying variant exon v6proved to be causal for the formation of distant metastases. Caution must be used when applying this information to humans. Although human pancreatic adenocarcinomas show v6 immunopositivity almost consistently, expression of v6 containing isoforms can also be detected in normal human ductal pancreatic cells. ${ }^{28}$

One of the first indications that aberrant splicing of CD44 was relevant to human tumour diagnosis was reported in $1992 .^{83}$ Reverse transcriptase polymerase chain reaction (RT-PCR) analysis followed by Southern blotting demonstrated that human colonic and breast carcinomas were usually associated with the generation of a number of large CD44 splicing isoforms.

These initial observations were followed by CD44 investigations of non-epithelial neoplasms. The results obtained with different types of cancer have demonstrated that more than one CD44 isoform is involved in tumour progression; tumour spreading related to expression of CD44 is mediated by various CD44 isoforms, depending on the type of the neoplasm (table 1).

\section{LYMPHOMAS}

The numerous attempts that have been made for a consensus classification of non-Hodgkin's lymphomas reflect the frequent unpredictability in behaviour and insufficient correlation between morphological and clinical features of these neoplasms. Consequently, active searches are being pursued to identify new markers enabling more accurate classification and prognosis. The role of CD44 in lymphocyte homing together with the transient upregulation of large CD44 isoforms in activated lymphoid : cells provided a rationale for assessing its $\overrightarrow{\bar{N}}$ potential participation in lymphoma progres- $\overline{0}$ sion. As a basis of this study, it was noticed that when the Namalwa lymphoma cell line was $\frac{\text { क }}{7}$ transfected with standard CD44, its metastatic $\stackrel{\mathbb{\Omega}}{\Omega}$ potential was greatly enhanced. ${ }^{84}$

Nodular lymphomas, which are relatively o indolent, are typically CD44 negative, in contrast to the usually more aggressive diffuse $\vec{\omega}$ lymphomas which are strongly CD44 positive. ${ }^{85}$ Overall, CD44 expression correlates 꾸 with poor prognosis in gastrointestinal of lymphoma. ${ }^{86} \mathrm{~A}$ substantial fraction of gastroin- iv testinal lymphomas reported in this study or (52\%) showed no expression of CD44 and 을 were characterised by a more favourable clini- $\rightarrow$ cal outcome. More detailed data can be $\frac{7}{0}$ obtained using reagents that are specific for alternatively spliced exons present in CD44 $\overrightarrow{\mathscr{C}}$ variant isoforms. The CD44 transcripts found in diffuse large cell lymphomas contain alternative splicing products which are not expressed in normal resting lymphocytes and resemble those found in activated B cells. ${ }^{87}$ Overexpression of isoforms containing protein product of $\mathbb{\perp}$ exons v3, v6, and v9 (but not v4) was observed $\overrightarrow{\vec{A}}$ in high grade lymphomas, as opposed to the low grade lymphoid neoplasms. ${ }^{7088}$ Additionally, multivariate analysis of morphological, clinical and molecular parameters obtained in a large cohort of patients with high grade non-Hodgkin's lymphoma demonstrated that the presence of CD44 v6 product was an independent prognostic factor. ${ }^{89}$ Interestingly, CD44 negative human Burkitt's lymphoma 은 cells transfected with large variant CD44 isoforms showed weaker adhesion to hyaluronate and increased aggressiveness, as documented by in vivo tests. ${ }^{51}$ The causal relation- $\sigma$ ship between these two phenomena has not $N$ been proved but it is tempting to speculate that $\mathrm{C}$ the decreased affinity to extracellular matrix can facilitate mobilisation of lymphoma cells $\stackrel{0}{\varnothing}$ and promote their spread via blood and $\stackrel{D}{\mathscr{D}}$ lymphatic vasculature.

However, at least in animal models, determinant factors other than CD44 relate to the aggressiveness of lymphoma. For instance, the MDAY-D2 murine lymphoma line in which CD44 is inactivated retains both its local invasiveness and metastatic potential, despite a 응 complete loss of hyaluronan binding ability. ${ }^{90}$ The level of soluble standard form and v6 containing CD44 isoforms can be measured in the blood of lymphoma patients and behaves as a useful marker in monitoring the effects of therapy. ${ }^{91}$

In contrast to non-Hodgkin's lymphomas, the role of CD44 and its variants in the biology of Hodgkin's disease is not understood. The CD44 status of Reed-Sternberg cells is un- 
clear, as is the relevance of the CD44 molecule to the prognosis of Hodgkin's disease.

\section{MELANOMA}

Human non-neoplastic melanocytes as well as some established melanoma cell lines are characterised by the presence of standard CD44 and the absence of variant isoforms. ${ }^{3492}$ In addition, examination of various human melanocytic lesions from benign pigmented naevi to metastatic deposits of melanoma, demonstrates a complex pattern of CD44 expression. Isoforms resulting from alternative splicing and containing products of exon v5 can be detected in some naevi and their expression increases in overtly malignant lesions. ${ }^{92}$ Conversely, v10 containing variant isoforms which are strongly upregulated in benign naevi, are less commonly expressed in atypical naevi, early melanomas, advanced melanomas, and metastases. Products of exon v6 have not been detected in human melanocytic lesions but are identified in some melanoma cell lines, correlating positively with metastatic potential after injection in nude mice. The same in vivo tests showed an even stronger relationship between v5 and metastatic phenotype. This is in keeping with the recent observation that CD44v5 expression correlates with lymph node metastases in human melanomas, suggesting that CD44v5 may be responsible for binding of neoplastic melanocytes to antigen presenting cells within lymph nodes. ${ }^{93}$ Binding could be followed by secretion of cytokines promoting survival of the metastatic focus.

The study of melanomas provides an opportunity to investigate how CD44 expression might relate to the presence of its ligand, hyaluronan, in the tumour microenvironment, and how tumour cells themselves contribute to hyaluronan deposition. Highly metastatic melanoma cell lines produce more hyaluronan than cell lines showing poor or no metastatic capacity. ${ }^{94}$

There is a direct link between hyaluronan binding and the aggressiveness of human melanoma cell lines. Cells transfected with CD44 mutated at arginine 41 in exon s2, an essential site for hyaluronan recognition, not only completely lose lectin function but also have a dramatically reduced aggressiveness. ${ }^{95}$ Markedly different behaviour can be observed when human melanoma cells are sorted according to the intensity of CD44 expression. The clones characterised by the highest CD44 expression show, in addition to a stronger adhesion to hyaluronan, a more vigorous motility and homotypic aggregation. They also have an increased capacity to colonise lungs of nude mice injected subcutaneously with tumour cell suspensions. ${ }^{96}$

\section{COLORECTAL CARCINOMA}

Colorectal carcinoma develops usually through a well recognised sequence of events: flat or slightly elevated foci of dysplastic crypt(s), adenoma with increasing grade of dysplasia, intramucosal carcinoma, and finally overtly malignant neoplasm invading the deep layers of the intestinal wall and spreading to the neighbouring lymph nodes and distant organs. The prognosis of patients with intramucosal carcinoma is usually excellent and the prognosis of those with invasion beyond bowel wall and distant metastases is invariably poor. The behaviour of the most frequent colorectal cancers which are diagnosed at an intermediate stage, is often unpredictable.

Normal cells of adult human large intestinal epithelium express standard CD44 and less prominently $\mathrm{v} 5, \mathrm{v} 7$, and $\mathrm{v} 9$ containing isoforms in the basal region of epithelial crypts. Isoforms containing the products of exons $v 4$ and $v 6$ are not detected by immunohistochemistry in adult colorectal epithelium. ${ }^{97}{ }^{98}$ Fetal colonic epithelial cells are CD44 negative. ${ }^{25} 26$

Immunohistochemical examination of paraffin embedded colorectal tissue specimens, using a monoclonal antibody recognising all isoforms of CD44 molecules, demonstrates that its accumulation can be found in early, small adenomas, becoming more frequent in larger lesions and carcinomas. ${ }^{99}$ Furthermore, CD44 overexpression precedes other genetic changes, like K-ras mutation, DCC deletion, and expression of abnormally stable p53. K-ras mutation is usually found before malignant transformation of colorectal neoplasms; therefore, CD44 upregulation is an earlier marker of colonic epithelium transformation than ras mutations.

Colonic adenomas and carcinomas display isoforms containing different sequences encoded by exons v3-v10, which are not encountered at a high level in normal colonic epithelium. ${ }^{100101}$ Furthermore, in adenomatous polyps the presence of these atypical variants correlates with histologically identified areas of dysplasia. At the mRNA level, RT-PCR analysis of transcripts shows that there is a greater number of isoforms containing v8-v10 sequences in colonic carcinoma than in normal autologous colonic mucosa. ${ }^{102}$ The same change can also be seen by in situ hybridisation and Northern blot experiments (fig 2).

Immunohistochemical investigations with antibodies specific for discrete variant exon products have documented the pattern of CD44 isoform expression in colon cancer. ${ }^{97} 98$ The isoforms containing sequences encoded by alternatively spliced exons v 5 and v 6 can be seen in lesions as early as small adenomas (diameter $<1 \mathrm{~cm}$ ). In particular, v5 is strongly positive in almost all adenomas, whereas v6 lags behind, being positive in $17 \%$ of early adenomatous lesions, reaching $82 \%$ positivity in advanced carcinomas (Dukes' C or D) (fig 3 ). In contrast to v5, v6 expression correlates positively with the grade of dysplasia in premalignant tumours. Overall, the acquisition of exon v5 expression occurs early in colorectal tumour development. CD44 isoforms containing v6 appear later, characterise a large subset of neoplasms, probably correspond chronologically to the p53 mutations, and lead to a growth advantage of positive tumour cell subclones. ${ }^{98}$ Antibodies against epitopes encoded by exon v7 and v8-v10 react strongly with neoplastic cells of adenomas and carcino- 

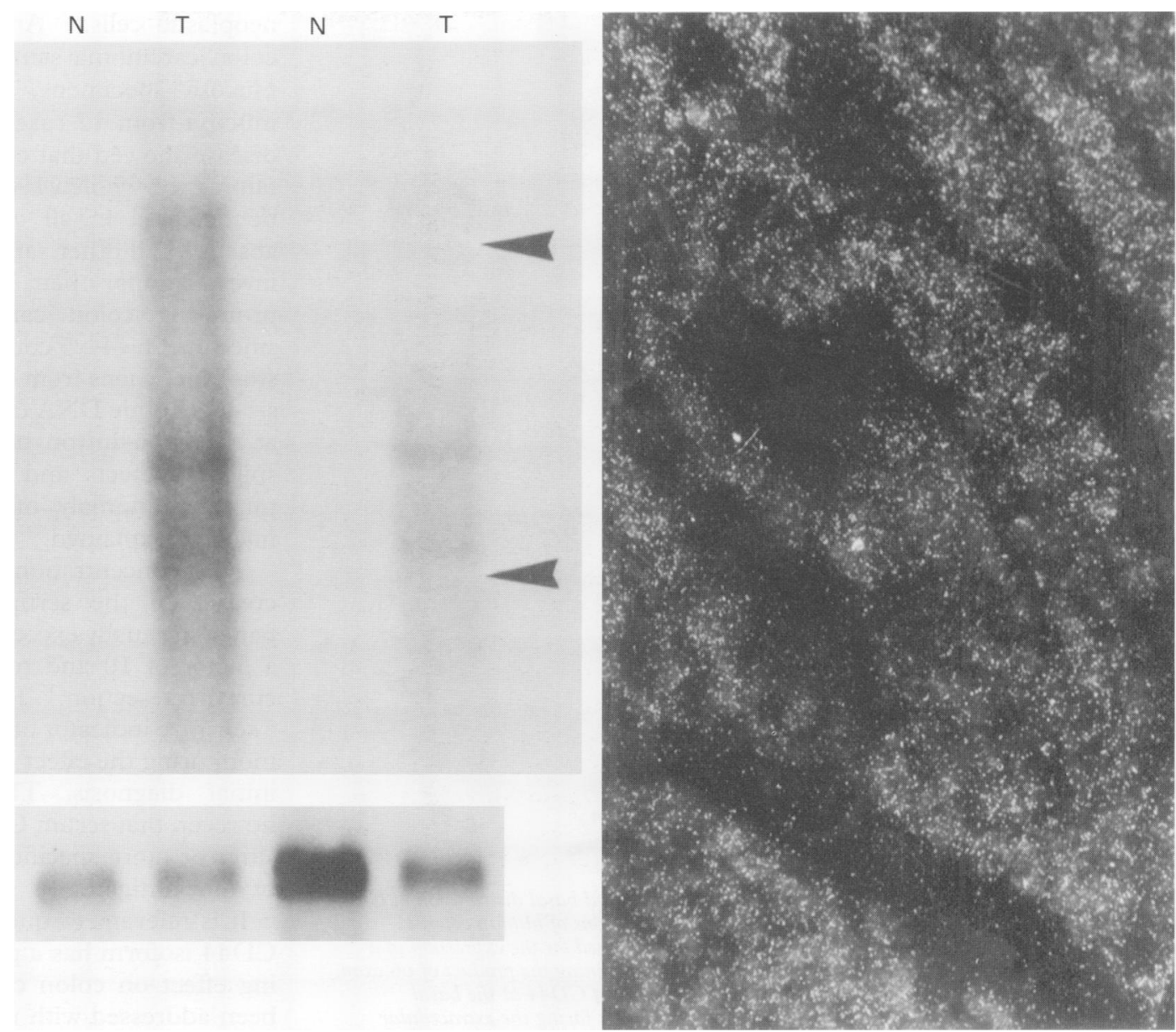

Figure 2 Selective expression of alternatively spliced variant CD44 in carcinomas. Left, Northern blot analysis of two cases of colonic carcinoma. The membrane was probed with a cDNA consisting of the CD44 v8-v10 sequence. $\beta$ actin load controls are on the lower left panel. Three transcripts of 2.0,2.6, and $5.1 \mathrm{~kb}$ are detected in the tumour $(T)$ but not in the autologous normal (N) mucosa. The arrowheads indicate the position of $18 S$ and $28 S$ RNA. Right, in situ hybridisation of a colonic carcinoma tissue section with a ${ }^{35} S$ labelled CD44 v8-v10 riboprobe. It shows a strong signal in the neoplastic glands and no detectable signal in the stromal cells. (Original magnification $\times 140$ ).

mas. No products of exon v3 are detected in normal or neoplastic colonic epithelium..$^{97}$

Divergent conclusions have been reached regarding a potential relationship between variant CD44 expression and the prognosis of patients with colorectal carcinoma. Protein expression of standard and variant isoforms of CD44 correlates with a poor prognosis in colon cancer as shown by an almost threefold deterioration in five year survival for patients who have an overexpression of CD44 in their tumour, confirming an earlier report. ${ }^{103} 104$ In a retrospective analysis the expression of $\mathrm{v} 6$ containing CD44 variants, assessed semiquantitatively, emerged as an adverse prognostic factor independent of Dukes' stage. ${ }^{105}$

A prospective study of a larger group of patients reported slightly different results. ${ }^{106}$ Although v6 is definitely upregulated as early as in adenomas, its overexpression could not be established as an independent outcome related parameter. Furthermore, there is a striking downregulation of $\mathrm{v} 6$ in metastatic lesionsonly $17 \%$ remain weakly positive, compared with $66 \%$ positive among metastasising primary tumours. Recently, a similar phenomenon was reported by Sugino et al, who demonstrated that the overexpression of both standard and variant CD44 mRNAs and proteins was less prominent in more advanced bladder cancers both in terms of grading and staging. ${ }^{107}$ It is therefore possible that, at least in some neoplasms, various CD44 isoforms play only a transient role in progression towards a more malignant phenotype.

Alternatively, deep invasion, which is usually achieved by smaller clumps of tumour cells or even single cells, might be less dependent on CD44 mediated adhesion. Investigating protein expression using exon specific antibodies has the advantage of relating CD44 expression to individual tumour cells in colorectal cancers but is less helpful in defining the splicing pattern. Equally important is the knowledge of which combinations of CD44 mRNA variant transcripts are expressed in these tumours. This information can be gained from RT-PCR studies. ${ }^{100} 108109$ This approach provides information mostly on tumour cells, although a minor proportion of benign cells are also present in the tumour extracts. Using RT-PCR, it is possible to distinguish patients with a relatively good prognosis ( $65 \%$ survival at five years) who have tumours with mostly standard CD44 transcripts, from patients whose tumours have a high content of CD44 v8-v10 transcripts (20\% survival at five years). ${ }^{100}$ Furthermore, high expression of v6 and v8-v10 transcripts in colorectal cancer correlates with the presence of liver metastases. ${ }^{108110}$

Detailed topographic data on localisation of various CD44 mRNAs in colonic cancer speci- 


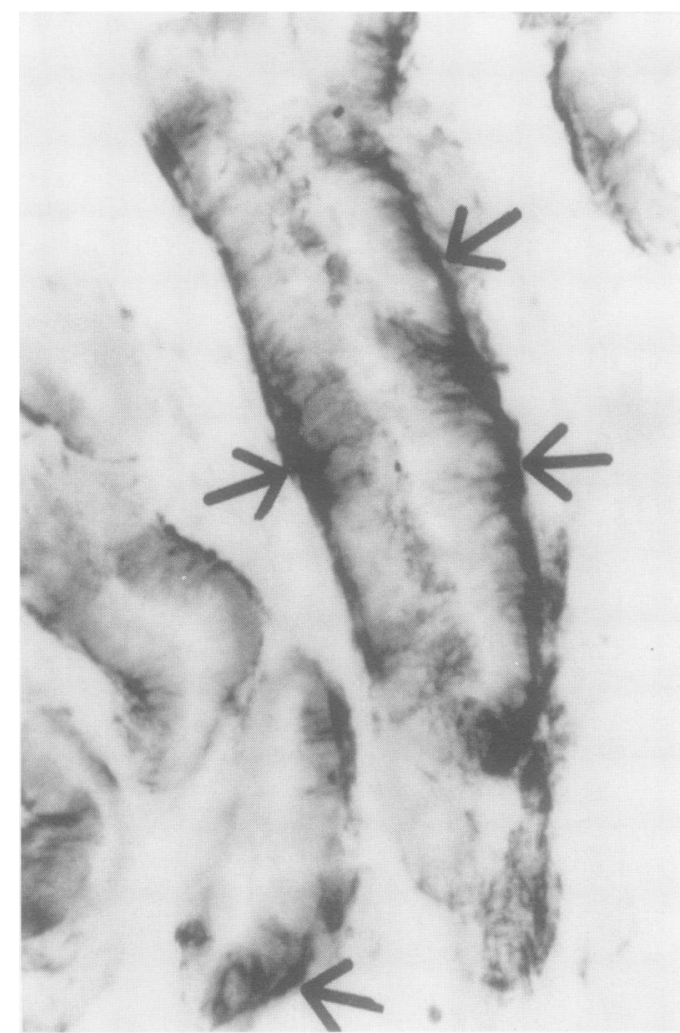

Figure 3 Overexpression and basal distribution of CD44 in carcinomas. Cryostat sections of human colonic carcinoma were immunostained for the expression of a variant CD44 isoform containing the product of v6 exon. There is a strong expression of CD44 at the basal membrane of the tumour cells facing the extracellular matrix (arrows). Tumour cells in some parts of the neoplastic glands also express CD44 on their lateral membrane. No v6 containing CD44 isoforms were detected when the normal mucosa was immunostained. FW11-9 monoclonal antibody, immunoperoxidase staining of frozen section, light haematoxylin counterstaining. (Original magnification $\times 140$ ).

mens have recently been reported. ${ }^{111}{ }^{112}$ Radioactive in situ hybridisation with probes specific for variant or standard CD44 allowed the identification of neoplastic but not stromal cells as a source of abundant variant CD44 transcripts. In the latter study ${ }^{12}$ in situ hybridisation was successfully applied to paraffin embedded specimens, despite low abundance of CD44 message at the mRNA level.

The presence of several species of CD44 transcripts in colonic tumour extracts suggests that tumour cells have dysregulated splicing mechanisms compared with untransformed epithelial cells. Supporting this notion is the observation of a retained intron in the CD44 transcripts of colonic carcinoma. ${ }^{113}$ The retained intron, located between $\mathrm{v} 4$ and $\mathrm{v} 5$, was originally described in a bladder cancer cell line and clinical specimens of bladder carcinomas. It was found in $77 \%$ of bladder carcinoma specimens and proved to be specific as it was not detected in $95 \%$ of the control cases. ${ }^{114}$ The authors of this study reported the failure of several other CD44 intronic sequences to be edited out in purified fraction of cytoplasmic mRNA from bladder malignant tumours. However, their subsequent work demonstrated that introns of CD44 mRNAs were also retained in cytoplasm of some squamous nonneoplastic epithelia, whereas in glandular epithelia this phenomenon was confined to neoplastic cells. ${ }^{115}$ Analysis encompassing 15 colon carcinoma samples, autologous normal mucosa specimens, and sections of colon mucosa from 12 cases of inflammatory bowel disease showed that cytoplasmic mRNAs containing the whole $\mathrm{v} 4-\mathrm{v} 5$ intron sequence could be detected in all cancer specimens, being absent in all other samples. ${ }^{113}$ Moreover, these investigations open perspectives of a new promising colon cancer screening method since intron v4-v 5 could be detected in $73 \%$ of stool specimens from cancer patients. ${ }^{116}$ Analysis of genomic DNA clones excludes mutations at the exon-intron boundaries as a cause of splicing defects and the mechanism of this puzzling anomaly of mRNA processing remains unexplained. ${ }^{114}$

The concentration of soluble CD44 increases in the serum of colorectal cancer patients, usually exceeding the normal value by a factor of 10 and returning to normal after curative resection. ${ }^{36}$ Thus, it can be assayed as a sensitive indicator of tumour burden useful in monitoring the effect of therapy, rather than in initial diagnosis. There is no indication, however, that serum CD44 could be more sensitive or more specific than serum carcinoembryonic antigen.

It is relevant to question whether a specific CD44 isoform has a promoting or a suppressing effect on colon cancer, an issue that has been addressed with recent experiments using nude mice xenotransplanted with manipulated cell lines. ${ }^{109} 117$ Expression of standard CD44 in colonic cancer cells that do not normally express it, led to a markedly diminished tumorigenicity; this reduction required an intact cytoplasmic domain. At the same time the cells adhered more strongly to hyaluronan, a function typically associated with the standard isoform of CD44. Taken together, these observations suggest that the standard isoform of CD44 might have tumour suppressor properties. This suggestion cannot be generalised, however, as different human tumours have a different biology in this respect. Indeed, comparable experiments performed with a melanoma cell line showed that the standard isoform of CD44 promoted tumorigenicity in non-epithelial neoplasms. ${ }^{95}$ The exact mechanisms whereby CD44 isoforms containing alternatively spliced exons increase the malignant potential of colonic carcinoma cells is unclear. It is possible that blood group $\mathrm{H}$ antigen, which can form a complex with the v6 exon of CD44, participates in tumorigenicity. In a rat colonic adenocarcinoma cell line the same antigen was responsible for high tumorigenicity, whereas inhibition of fucosylation not only abrogated its presentation but also markedly reduced tumour growth in syngeneic rats. ${ }^{18}$ Thus, once again, the way CD44 radically modifies cell behaviour seems to be dependent on the unique pattern of glycosylation, itself determined by alternative splicing. It has been established that the expression of this carbohydrate antigen correlates negatively with the prognosis of human colorectal cancer. ${ }^{118}$ 


\section{GASTRIC CARCINOMA}

Expression of CD44 in the mucosa of normal human stomach resembles the normal pattern of the intestinal epithelium: standard CD44 is present in most epithelial cells, with the exception of those situated in the apical parts of the glands. Isoforms containing products of exon v9 are confined to the basal parts of the glands. ${ }^{25}$ To some extent the analogies in CD44 expression also apply to the neoplasms in these two organs. Carcinomatous gastric mucosa is characterised by a relative predominance of transcripts derived from the epithelial isoform (CD44E), containing sequence v8-v10, over the standard transcript. ${ }^{119}$ Additionally this transcript expression pattern correlates positively with adverse features such as depth of invasion, blood and lymphatic vessel invasion, and presence of lymph node and hepatic metastases. ${ }^{119120}$ Gastric carcinomas also express the products of $v 5$ and $v 6$ exons with a specificity that relates to the histological subtype-the intestinal type of gastric adenocarcinoma displays v 5 and v6 containing CD44 isoforms, whereas the diffuse type of tumour expresses v5 but not v6. ${ }^{121}$ This specificity in CD44 variant expression for the intestinal type of gastric carcinoma is highly consistent with the presence of both v5 and v6 exon products in intestinal metaplasia of the stomach, a change considered putatively premalignant.

\section{THYROID CARCINOMA}

The pattern of CD44 expression corresponds with the histological features in the two most frequent types of thyroid carcinoma: follicular and papillary. Overall, expression of CD44 is stronger than in non-neoplastic thyroid tissue for both types of carcinoma. Almost all papillary tumours overexpress the v6 isoform of CD44, as opposed to nearly all follicular neoplasms which are negative for this marker. ${ }^{122}$ Considering that papillary carcinomas of the thyroid have a marked tendency to metastasise to lymph nodes, it appears logical to suggest that the v6 variant of CD44 is involved in this metastatic homing.

\section{OTHER CARCINOMAS}

The detailed characterisation of CD44 in human colonic cancer has been accompanied by studies of other human carcinomas: breast, ${ }^{123-125}$ pancreas, ${ }^{28}{ }_{126-128}$ endometrium, ${ }^{129}$ cervix, ${ }^{130131}$ ovary, ${ }^{35132}$ nasopharynx, ${ }^{133}$ lungs, ${ }^{134}$ gastrointestinal neuroendocrine system, ${ }^{135}$ and others. ${ }^{33}$ The overall picture on the role of CD44 in the progression of carcinomas and related (neuroendocrine) neoplasms points to a dysregulation of alternative splicing, resulting in the generation of unusual, large transcripts, usually accompanied by the translation of high levels of corresponding protein products. Despite some discrepancies between the studies, the neoplasms exhibiting stronger CD44 expression, especially those producing atypical CD44 variants, tend to behave more aggressively. In particular, the expression of the exon v6 product is often associated with adverse clinical and morphological features, mainly with lymph node metastasis.

In the case of breast carcinoma, the investigation of clinical significance of $v 6$ expression led to divergent conclusions. In a study of 91 patients with a median follow up of 35 months, 음 CD44 expression was found to be an indicator of poor prognosis in terms of overall survival. ${ }^{124}$ In contrast, in a study of a larger cohort (227 patients with median observation time $57 \stackrel{\vec{s}}{\stackrel{\bar{S}}{9}}$ months), expression of none of the variant $\overline{0}$ exons, including v6, was found to correlate with the clinical outcome. ${ }^{123}$ However, this report found that v6 correlated positively with $\stackrel{\square}{\Omega}$ tumour grade and steroid receptor status.

In an investigation of lung adenocarcinoma using an antibody that does not distinguish standard from variant CD44 isoforms, a poor $\vec{\omega}$ prognosis was associated with decreased CD44 expression. ${ }^{136}$ Furthermore, in nine cases of small cell carcinoma of the lung, no CD44 of expression was found, which contrasts with the iv positive reaction of most non-small cell pri- G mary lung carcinomas. ${ }^{134}$

The results of these studies contribute to the complexity of interrelations between CD44 $\frac{7}{0}$ expression and behaviour of neoplastic cells. They contrast with most of the analogous $\vec{\bullet}$ research on gastrointestinal tumours, but seem . to support the experimental data showing that reintroduction of $\mathrm{CD} 44 \mathrm{H}$ into colonic carcinoma cells reduces their tumorigenicity. ${ }^{109}$

In addition to carcinomas characterised by either positive or negative associations between $\triangle$ clinical outcome and expression of CD44, $\overrightarrow{\overrightarrow{0}}$ there are also some carcinomas in which com- 3 plete data on prognostic significance (as defined by overall survival and recurrence free survival) are unknown. Nevertheless, in these tumours, CD44 expression has been compared with specific pathological and clinical features. For instance, in ovarian serous carcinoma there was a link between the CD44 on the surface of cancer cells and the way in which the tumour $\mathrm{O}$ spread in the peritoneal cavity. ${ }^{137}$ CD 44 negative ovarian carcinomas tend to form ascites, whereas CD44 positive ones grow solid peritoneal implants. Furthermore, the adhesion of ovarian adenocarcinoma cells to mesothelium is hyaluronan and CD44 dependent.

Finally, CD44 expression may be helpful in differential diagnosis, as renal oncocytomas have been demonstrated to be invariably CD44 negative, whereas chromophobe renal carcinomas tend to express CD44 including the $\mathbb{\mathbb { D }}$ variant isoforms. ${ }^{138}$ In clear cell and $\mathbb{D}$ chromophilic carcinomas analysed in this study, a positive correlation was shown between progression from grade $\mathrm{G} 1$ to $\mathrm{G} 3$ and 8 expression of exons $\mathrm{v} 6$ and $\mathrm{v} 9$ as well as standard CD44.

OTHER NEOPLASMS

In contrast to carcinomas and lymphomas, data on CD44 expression in other neoplasms are rather scant. The expression of CD44 by mesenchymal and neural tissues is usually confined to the standard form of the molecule. In 
the few neoplasms in which CD44 production was analysed, this pattern of expression was generally retained, the standard form being the only, if any, detectable isoform.

Observations concerning neuroblastoma are particularly interesting. CD44 is downregulated in advanced neuroblastomas (stage IV), whereas the earlier (I, II, III) or advanced but prognostically favourable stages are characterised by tumour cells maintaining their ability to synthesise the standard form of CD44..$^{139-141}$ Approximately half of the stage IV tumours diagnosed lost CD44 expression, resembling the phenotype typical for early neural crest cells. ${ }^{141}$ Furthermore, preservation of CD44 was inversely correlated with $\mathrm{N}-m y c$ amplification, these two parameters being the only statistically independent prognostic factors in multivariate analysis. ${ }^{142}$ Northern blot as well as immunohistochemistry with antibodies specific for variant exons products demonstrated that the standard isoform of CD44 was the only one present in neuroblastomas. ${ }^{140}$ However, it is unclear how the suppression of CD44 expression modifies the properties of neuroblastoma cells.

In contrast, glioblastomas tend to show a completely different phenotype. These invariably highly malignant neoplasms showed strong immunostaining with anti-CD44 antibodies recognising the standard form of CD44. ${ }^{143}$ Complementary studies indicated that the expression of variant CD44 isoforms can be seen in many glioblastomas, but usually confined to only a few neoplastic cells. ${ }^{144}$ Highly malignant gliomas tend to contain clusters of v5 positive cells, whereas v6 positive foci could be found in many gliomas irrespective of the grade. ${ }^{145}$ Peripheral schwannomas were characterised by a high expression of CD44 variants with sequences encoded by exon v5, and $\mathrm{v} 7-\mathrm{v} 10,{ }^{146}$ meningiomas were CD44 negative. ${ }^{143}$

\section{Conclusions}

In the past few years basic and clinical research on CD44 have led to a set of challenging new concepts. Initially described as a molecule mostly involved in lymphocyte homing, it is now apparent that CD44 plays major roles in the biology of cancer cells. Although early evidence implicated CD44 in the determination of metastasis, it is clear that its role in tumour progression occurs at a much earlier stage of the transformation process. The pleiotropic expression of CD44 in many non-neoplastic and neoplastic cells is not an indication that it is unrelated to tumour progression. Indeed, knowledge of the genomic DNA structure and alternative splicing pattern of CD44 have identified clearly that it is not one but a family of proteins, and that discrete isoforms are expressed and regulated at various stages of malignant transformation. The clinicopathological counterpart of this differential expression of specific isoforms can be summarised by stating that for most, but not all, cancers overexpression of discrete species of CD44 correlates with tumour aggressiveness. A challenging area of research would be to define what cellular functions are associated with the various isoforms of CD44 that are overexpressed in cancer. How cell adhesion properties might be gained or lost by these isoforms is an unresolved issue, as is understanding the adhesion to the various ligands found in peritumoral stroma.

We thank Dr Sean Moore for a critical analysis of this review; Lam Leduy, Diane McClure, and Roya Haghighat for their contribution to the figures; and Dr Ursula Günthert for helpful discussions, and for providing antibodies and probes. Supported by grants to SJ from the Medical Research Council (\#MT10315) and the National Cancer Institute of Canada (\#4534) $\mathrm{ZR}$ is supported by a Hans and Eugenia Jütting Fellowship.

1 Cobbold S. Human leukocyte differentiation antigens: monoclonal antibody computer databases as a tool for the future. Mol Cell Probes 1987;1:61-72.

2 Dalchau R, Kirkley J, Fabre JW. Monoclonal antibody to a human brain-granulocyte- $T$ lymphocyte antigen probably homologous to the W $3 / 13$ antigen of the rat. Eur $\mathcal{F}$ Immunol 1980;10:745-9.

3 Haynes BF, Liao HX, Patton KL. The transmembrane hyaluronate receptor (CD44): multiple functions, multiple forms. Cancer Cells 1991;3:347-50

4 Lesley J, Hyman R, Kincade PW. CD44 and its interaction with extracellular matrix. Adv Immunol 1993;54:271-335.

Goodfellow PN, Banting G, Wiles MV, Tunnacliffe A Parkar M, Solomon E et al. The gene, MIC4, which conParkar $M$, Solo body F10.44.2, is on human chromosome 11. Eur f Immubody F10.44.2, is on

6 Screaton GR, Bell MV, Jackson DG, Cornelis FB, Gerth U, Bell JI. Genomic structure of DNA encoding the lymphocyte homing receptor CD44 reveals at least 12 alternatively spliced exons. Proc Natl Acad Sci USA 1992;89:12160-4.

7 Tölg C, Hofmann M, Herrlich P, Ponta H. Splicing choice from ten variant exons establishes CD44 variability. Nucleic Acids Res 1993;21:1225-9.

8 Screaton GR, Bell MV, Bell JI, Jackson DG. The identification of a new alternative exon with highly restricted tissue expression in transcripts encoding the mouse Pgp-1 (CD44) homing receptor. Comparison of all 10 variable exons between mouse, human, and rat. $\mathcal{F}$ Biol Chem 1993; 268: $12235-8$

9 Sherman L, Sleeman J, Herrlich P, Ponta H. Hyaluronate receptors: key players in growth, differentiation, migration and tumor progression. Curr Opin Cell Biol 1994;6:726-33.

10 Cooper DL, Dougherty GJ. To metastasize or not? Selection of CD44 splice sites. Nat Med 1995;1:635-7.

11 Kugelman LC, Ganguly S, Haggerty JG, Weissman SM, Milstone LM. The core protein of epican, a heparan sulfate proteoglycan on keratinocytes, is an alternative form of proteoglycan on keratinocytes, is an alte
CD44. F Invest Dermatol 1992;99:886-91.

12 Stamenkovic I, Amiot M, Pesando JM, Seed B. A lymphocyte molecule implicated in lymph node homing is a member of the cartilage link protein family. Cell 1989;56 $1057-62$.

13 Nottenburg C, Rees G, St John T. Isolation of mouse CD44 cDNA: structural features are distinct from the primate cDNA. Proc Natl Acad Sci USA 1989;86:8521-5.

14 Yang B, Yang BL, Savani RC, Turley EA. Identification of a common hyaluronan binding motif in the hyaluronan binding proteins RHAMM, CD 44 and link protein. EMBO f 1994;13:286-96.

15 Peach RJ, Hollenbaugh D, Stamenkovic I, Aruffo A. Identification of hyaluronic acid binding sites in the extracellular domain of CD44. $\mathcal{F}$ Cell Biol 1993;122:257-64.

16 Liao HX, Lee DM, Levesque MC, Haynes BF. N-terminal and central regions of the human CD44 extracellular domain participate in cell surface hyaluronan binding. $\mathcal{F}$ Immunol 1995;155:3938-45.

17 Jackson DG, Bell JI, Dickinson R, Timans J, Shields J, Whittle N. Proteoglycan forms of the lymphocyte homing receptor CD44 are alternatively spliced variants containing the v3 exon. $f$ Cell Biol 1995;128:673-85.

18 Labarrière N, Piau JP, Otry C, Denis M, Lustenberger P, Meflah $\mathrm{K}$, et al. $\mathrm{H}$ blood group antigen carried by CD $44 \mathrm{~V}$ modulates tumorigenicity of rat colon carcinoma cells. Cancer Res 1994;54:6275-81.

19 Goldstein LA, Butcher EC. Identification of mRNA that encodes an alternative form of H-CAM(CD44) in lymphoid and nonlymphoid tissues. Immunogenetics 1990; lymphoid and

20 Lokeshwar VB, Bourguignon LY. The lymphoma transmembrane glycoprotein GP85 (CD44) is a novel guanine membrane glycoprotein GP85 (CD44) is a novel guanine nucleotide-binding protein which regulates GP85 (CD
ankyrin interaction. $\mathcal{F}$ Biol Chem 1992;267:22073-8.

21 Lokeshwar VB, Fregien N, Bourguignon LY. Ankyrinbinding domain of CD44(GP85) is required for the expression of hyaluronic acid-mediated adhesion function f Cell Biol 1994;126:1099-109.

22 Bennett KL, Modrell B, Greenfield B, Bartolazzi A, Stamenkovic I, Peach R, et al. Regulation of CD44 binding to hyaluronan by glycosylation of variably spliced exons. Cell Biol 1995;131:1623-33. 
23 Hardingham TE, Fosang AJ. Proteoglycans: many forms and many functions. FASEB 7 1992;6:861-70.

24 Stamenkovic I, Aruffo A, Amiot M, Seed B. The hematopoietic and epithelial forms of CD44 are distinct polypeptides with different adhesion potentials for hyaluronate-bearing cells. $E M B O \mathcal{F} 1991 ; 10: 343-8$.

25 Terpe HJ, Stark H, Prehm P, Günthert U. CD44 variant isoforms are preferentially expressed in basal epithelial of non-malignant human fetal and adult tissues. Histochemis try 1994;101:79-89.

26 Mackay CR, Terpe HJ, Stauder R, Marston WL, Stark H, Günthert U. Expression and modulation of CD44 variant isoforms in humans. 7 Cell Biol 1994;124:71-82.

27 Iida N, Bourguignon LY. New CD44 splice variants associated with human breast cancers. $\mathcal{f}$ Cell Physiol 1995;162 $127-33$.

28 Gansauge F, Gansauge S, Zobywalski A, Scharnweber C Link KH, Nussler AK, et al. Differential expression of CD44 splice variants in human pancreatic adenocarcinom and in normal pancreas. Cancer Res 1995;55:5499-503.

29 Hong RL, Pu YS, Chu JS, Lee WJ, Chen YC, Wu CW. Correlation of expression of CD44 isoforms and E-cadherin with differentiation in human urothelial cell lines and tranwitional cell carcinoma. Cancer Lett 1995;89:81-7.

30 Southgate J, Trejdosiewicz LK, Smith B, Selby PJ. Pattern of splice variant CD44 expression by normal human urothelium in situ and in vitro and by bladder-carcinoma cell lines. Int $\mathcal{F}$ Cancer 1995;62:449-56.

31 Neame SJ, Isacke CM. Phosphorylation of CD44 in vivo requires both Ser 323 and Ser325, but does not regulate membrane localization or cytoskeletal interaction in epithelial cells. EMBO ₹ 1992;11:4733-8.

32 Isacke $\mathrm{CM}$. The role of the cytoplasmic domain in regulating CD44 function. 7 Cell Sci 1994;107:2353-9.

33 Herrlich P, Zoller M, Pals ST, Ponta H. CD44 splice variants: metastases meet lymphocytes. Immunol Today 1993;14:395-9.

34 Hofmann M, Rudy W, Zoller M, Tölg C, Ponta H, Herrlich $\mathrm{P}$, et al. CD44 splice variants confer metastatic behavior in rats: homologous sequences are expressed in human tumo cell lines. Cancer Res 1991;51:5292-7.

35 Sliutz G, Tempfer C, Winkler S, Kohlberger P, Reinthaller A, Kainz C. Immunohistochemical and serological evalua tion of CD44 splice variants in human ovarian cancer. $\mathrm{Br} f$ Cancer 1995;72:1494-7.

36 Guo YJ, Liu G, Wang X, Jin D, Wu M, Ma J, et al. Potential use of soluble CD44 in serum as indicator of tumor burden and metastasis in patients with gastric or colon cancer. Cancer Res 1994;54:422-6.

37 Underhill CB, Chi-Rosso G, Toole BP. Effects of detergent solubilization on the hyaluronate-binding protein from membranes of simian virus 40 -transformed $3 \mathrm{~T} 3$ cells. $\mathcal{F}$ Biol Chem 1983;258:8086-91.

38 Underhill CB, Thurn AL, Lacy BE. Characterization and identification of the hyaluronate binding site from membranes of SV-3T3 cells. F Biol Chem 1985;260:8128-33.

39 Underhill CB, Green SJ, Comoglio PM, Tarone G. The hyaluronate receptor is identical to a glycoprotein of $\mathrm{Mr}$ 85.000 (gp85) as shown by a monoclonal antibody that interferes with binding activity. $\mathcal{F}$ Biol Chem 1987;262: interferes

40 Miyake K, Underhill CB, Lesley J, Kincade PW. Hyaluronate can function as a cell adhesion molecule and CD44 participates in hyaluronate recognition. $f$ Exp Med participates in

41 Zheng Z, Katoh S, He Q, Oritani K, Miyake K, Lesley J, et al. Monoclonal antibodies to CD44 and their influence on hyaluronan recognition. $\mathcal{f}$ Cell Biol 1995;130:485-95.

42 Koshiishi I, Shizari M, Underhill CB. CD44 can mediate the adhesion of platelets to hyaluronan. Blood 1994;84:3906.

43 Milstone LM, Hough-Monroe L, Kugelman LC, Bende JR, Haggerty JG. Epican, a heparan/chondroitin sulfate proteoglycan form of CD44, mediates cell-cell adhesion. $\mathcal{F}$ proteoglycan form of CD44,

44 Weber GF, Ashkar S, Glimcher MJ, Cantor H. Receptorligand interaction between CD44 and osteopontin (ETA1). Science 1996;271:509-12.

45 Underhill C. CD 44: the hyaluronan receptor. $\mathcal{F}$ Cell $S_{c i}$ 1992;103:293-8.

46 Thomas L, Byers HR, Vink J, Stamenkovic I. CD44H regulates tumor cell migration on hyaluronate-coated substrate. f Cell Biol 1992;118:971-7.

47 He O, Lesley J, Hyman R, Ishihara K, Kincade PW Molecular isoforms of murine CD44 and evidence that the membrane proximal domain is not critical for hyaluronate recognition. $\mathcal{F}$ Cell Biol 1992;119:1711-19.

48 Dougherty GJ, Cooper DL, Memory JF, Chiu RK. Ligand binding specificity of alternatively spliced CD44 isoforms. Recognition and binding of hyaluronan by CD44R1. $\mathcal{F}$ Bio Chem 1994;269:9074-8.

49 Droll A, Dougherty ST, Chiu RK, Dirks JF, McBride WH, Cooper DL, et al. Adhesive interactions between alternatively spliced CD44 isoforms. F Biol Chem 1995;270: tively spliced $11567-73$.

50 Lokeshwar VB, Bourguignon LY. Post-translational protein modification and expression of ankyrin-binding site(s) in GP85 (Pgp-1/CD44) and its biosynthetic precursors during T-lymphoma membrane biosynthesis. 7 Biol Chem 1991;266: 17983-9.

51 Bartolazzi A, Jackson D, Bennett K, Aruffo A, Dickinson R, Shields J, et al. Regulation of growth and dissemination of human lymphoma by $\mathrm{CD} 44$ splice variants. $\mathcal{f}$ Cell $S_{c i}$ 1995;108:1723-33.
52 Lesley J, He Q, Miyake K, Hamann A, Hyman R, Kincade PW. Requirements for hyaluronic acid binding by CD44z: a role for the cytoplasmic domain and activation by a role for the cytoplasmic domain

53 Lesley J, Schulte R, Hyman R. Binding of hyaluronic acid to lymphoid cell lines is inhibited by monoclonal antibodies against Pgp-1. Exp Cell Res 1990;187:224-33.

54 Laurent TC, Fraser JR. Hyaluronan. FASEB f 1992;6: \ 2397-404.

55 Culty M, Shizari M, Thompson EW, Underhill CB. Binding and degradation of hyaluronan by human breast cancer cell lines expressing different forms of CD44: correlation with invasive potential. 7 Cell Physiol 1994;160:275-86.

56 Knudson CB, Knudson W. Hyaluronan-binding proteins in development, tissue homeostasis, and disease. FASEB $\mathcal{F} \mathscr{G}$ 1993;7:1233-41.

57 Ruiz P, Schwarzler C, Günthert U. CD44 isoforms during $\frac{C}{O}$ differentiation and development. Bioessays 1995;17:17-24.

58 Bourguignon LY, Lokeshwar VB, Chen X, Kerrick WG. Hyaluronic acid-induced lymphocyte signal transduction $\mathbb{\nabla}$ and HA receptor (GP85/CD44)-cytoskeleton interaction. $\mathcal{F}$ Q Immunol 1993;151:6634-44.

59 Jalkanen S, Jalkanen M. Lymphocyte CD44 binds the COOH-terminal heparin-binding domain of fibronectin. $f \vec{O}$ Cell Biol 1992;116:817-25.

60 Ishii S, Ford R, Thomas P, Nachman A, Steele G Jr, Jessup $\vec{\omega}$ JM. CD44 participates in the adhesion of human colorectal carcinoma cells to laminin and type IV collagen. Surg Oncol 1993;2:255-64.

61 Toyama-Sorimachi N, Sorimachi H, Tobita Y, Kitamura F, Yagita $\mathrm{H}$, Suzuki $\mathrm{K}$, et al. A novel ligand for CD44 is ser- $\mathrm{O}$ glycin, a hematopoietic cell lineage-specific proteoglycan. iv Possible involvement in lymphoid cell adherence and acti- نy vation. F Biol Chem 1995;270:7437-44.

62 Bennett KL, Jackson DG, Simon JC, Tanczos E, Peach R, 윽 Modrell B, et al. CD44 isoforms containing exon V3 are responsible for the presentation of heparin-binding growth factor. $\mathcal{F}$ Cell Biol 1995;128:687-98.

63 Denhardt DT, Guo X. Osteopontin: a protein with diverse functions. FASEB F 1993;7:1475-82.

64 Bautista DS, Xuan JW, Hota C, Chambers AF, Harris JF. $\vec{\theta}$ Inhibition of Arg-Gly-Asp (RGD)-mediated cell adhesion to osteopontin by a monoclonal antibody against osteopontin. F Biol Chem 1994;269:23280-5.

65 Xuan JW, Hota C, Chambers AF. Recombinant GSThuman osteopontin fusion protein is functional in RGDdependent cell adhesion. 7 Cell Biochem 1994;54:247-55.

66 Hijiya N, Setoguchi M, Matsuura K, Higuchi Y, Akizuki S, Dे Yamamoto S. Cloning and characterization of the human osteopontin gene and its promoter. Biochem $\mathcal{F}$ 1994;303: 255-62.

67 Senger DR, Brown LF, Perruzzi CA, Papadopoulos-Sergiou A, Van de Water L. Osteopontin at the tumor/host interface. Functional regulation by thrombin-cleavage and $\supset$ consequences for cell adhesion. Ann NY Acad Sci 1995;760:83-100.

68 Jalkanen ST, Bargatze RF, Herron LR, Butcher EC A lymphoid cell surface glycoprotein involved in endothelial cell recognition and lymphocyte homing in man. Eur f Immunol 1986;16:1195-202.

69 Arch R, Wirth K, Hofmann M, Ponta H, Matzku S, Herrlich $\mathrm{P}$, et al. Participation in normal immune responses $\varrho$ of a metastasis-inducing splice variant of CD44. Science 1992;257:682-5

70 Koopman G, Heider KH, Horst E, Adolf GR, van den Berg 응 $\mathrm{F}$, Ponta $\mathrm{H}$, et al. Activated human lymphocytes and aggressive non-Hodgkin's lymphomas express a homo- $\frac{7}{0}$ logue of the rat metastasis-associated variant of CD44. $f$ 을 Exp Med 1993;177:897-904.

71 de los Toyos J, Jalkanen S, Butcher EC. Flow cytometric $N$ analysis of the Hermes homing-associated antigen on human lymphocyte subsets. Blood 1989;74:751-60.

72 O'Neill HC. Antibody which defines a subset of bone mar- $N$ row cells that can migrate to thymus. Immunology 1989;68: 59-65.

73 Horst E, Meijer CJ, Radaskiewicz T, van Dongen JJ, Pieters R, Figdor CG, et al. Expression of a human homing receptor (CD44) in lymphoid malignancies and related stages of $\mathscr{E}$ lymphoid development. Leukemia 1990;4:383-9.

74 Miyake K, Medina KL, Hayashi S, Ono S, Hamaoka T, Kincade PW. Monoclonal antibodies to Pgp-1/CD44 block $\bar{O}$ lympho-hemopoiesis in long-term bone marrow cultures. $f$ (D) Exp Med 1990;171:477-88.

75 Bourguignon LY, Walker G, Suchard SJ, Balazovich K. A lymphoma plasma membrane-associated protein with

76 Kalomiris EL, Bourguignon LY. Mouse T lymphoma cells contain a transmembrane glycoprotein (GP85) that binds ankyrin. f Cell Biol 1988;106:319-27.

77 Perschl A, Lesley J, English N, Trowbridge I, Hyman R. Role of CD44 cytoplasmic domain in hyaluronan binding.
Eur f Immunol 1995;25:495-501.

78 Murakami S, Shimabukuro Y, Miki Y, Saho T, Hino E, Kasai $\mathrm{D}$, et al. Inducible binding of human lymphocytes to hyaluronate via CD44 does not require cytoskeleton hyaluronate via $\mathrm{CD} 44$ does not require cytoskeleton
association but does require new protein synthesis. $\mathcal{f}$ association but does require.

79 Tsukita S, Oishi K, Sato N, Sagara J, Kawai A, Tsukita S. ERM family members as molecular linkers between the cell surface glycoprotein CD44 and actin-based cytoskeletons. $f$ Cell Biol 1994;126:391-401.

80 Sato N, Funayama N, Nagafuchi A, Yonemura S, Tsukita S, Tsukita S. A gene family consisting of ezrin, radixin and 
moesin. Its specific localization at actin filament/plasma membrane association sites. 7 Cell Sci 1992;103:131-43.

81 Günthert U, Hofmann M, Rudy W, Reber S, Zoller M, Haussmann I, et al. A new variant of glycoprotein CD44 confers metastatic potential to rat carcinoma cells. Cell 1991;65:13-24

82 Seiter S, Arch R, Reber S, Komitowski D, Hofmann M, Ponta $\mathrm{H}$, et al. Prevention of tumor metastasis formation by anti-variant CD44. F Exp Med 1993;177:443-55.

83 Matsumura Y, Tarin D. Significance of CD44 gene products for cancer diagnosis and disease evaluation. Lancet 1992;340:1053-8

84 Sy MS, Guo YJ, Stamenkovic I. Distinct effects of two CD44 isoforms on tumor growth in vivo. $\mathcal{F}$ Exp Med 1991; 174:859-66.

85 Fujiwara K, Yoshino T, Miyake K, Ohara N, Akagi T Expression of a lymphocyte adhesion molecule (CD44) in malignant lymphomas: relevance to primary site, histologi-
cal subtype and clinical stage. Acta Med Okayama 1993;47: cal subtype

86 Joensuu H, Ristamaki R, Klemi PJ, Jalkanen S. Lymphocyte homing receptor (CD44) expression is associated with poor prognosis in gastrointestinal lymphoma. $\mathrm{Br} f$ Cancer 1993;68:428-32.

87 Salles G, Zain M, Jiang WM, Boussiotis VA, Shipp MA Alternatively spliced CD44 transcripts in diffuse large-cell lymphomas: characterization and comparison with normal activated $\mathrm{B}$ cells and epithelial malignancies. Blood 1993;82:3539-47

88 Terpe HJ, Koopmann R, Imhof BA, Günthert U. Expression of integrins and CD44 isoforms in non-Hodgkin's lymphomas: CD44 variant isoforms are preferentially expressed in high-grade malignant lymphomas. $f$ Pathol 1994;174:89-100

89 Stauder R, Eisterer W, Thaler J, Günthert U. CD44 variant isoforms in non-Hodgkin's lymphoma: a new independent prognostic factor. Blood 1995;85:2885-99.

90 Driessens MHE, Stroeken PJM, Erena NFR, Vandervalk MA, Vanrijthoven EAM, Roos E. Targeted disruption of CD44 in mday-d2 lymphosarcoma cells has no effect on subcutaneous growth or metastatic capacity. 7 Cell Biol subcutaneous grow

91 Ristamaki R, Joensuu H, Salmi M, Jalkanen S. Serum CD44 in malignant lymphoma: an association with treatment response. Blood 1994;84:238-43.

92 Manten-Horst E, Danen EH, Smit L, Snoek M, Le Poole IC, Van Muijen GN, et al. Expression of CD44 splice variants in human cutaneous melanoma and melanoma cell lines is related to tumor progression and metastatic potenlines is related to tumor progress
tial. Int $\mathcal{f}$ Cancer $1995 ; 64: 182-8$.

93 Seiter S, Schadendorf D, Herrmann K, Schneider M, Rosel $\mathrm{M}$, Arch R, et al. Expression of CD44 variant isoforms in malignant melanoma. Clin Cancer Res 1996;2:447-56.

94 Van Muijen GN, Danen EH, Veerkamp JH, Ruiter DJ, Lesley J, van den Heuvel LP. Glycoconjugate profile and CD44 expression in human melanoma cell lines with different metastatic capacity. Int $\mathcal{f}$ Cancer 1995;61:241-8.

95 Bartolazzi A, Peach R, Aruffo A, Stamenkovic I. Interaction between CD44 and hyaluronate is directly implicated in the regulation of tumor development. $\mathcal{F}$ Exp Med 1994;180: 53-66.

96 Birch M, Mitchell S, Hart IR. Isolation and characterization of human melanoma cell variants expressing high and low levels of CD44. Cancer Res 1991;51:6660-7.

97 Wielenga VJ, Heider KH, Offerhaus GJ, Adolf GR, van den Berg FM, Ponta $\mathrm{H}$, et al. Expression of CD44 variant proteins in human colorectal cancer is related to tumor progression. Cancer Res 1993;53:4754-6.

98 Mulder JW, Wielenga VJ, Polak MM, van den Berg FM, Adolf GR, Herrlich P, et al. Expression of mutant p53 protein and CD44 variant proteins in colorectal tumorigenesis. Gut 1995;36:76-80.

$99 \mathrm{Kim} \mathrm{H}$, Yang XL, Rosada C, Hamilton SR, August JT CD44 expression in colorectal adenomas is an early event occurring prior to K-ras and p53 gene mutation. Arch Biooccurring prior to K-ras and $\mathrm{p} 53$
chem Biophys 1994;310:504-7.

100 Finn L, Dougherty G, Finley G, Meisler A, Becich M, Cooper DL. Alternative splicing of CD44 pre-mRNA in human colorectal tumors. Biochem Biophys Res Commu 1994;200:1015-22.

101 Heider KH, Hofmann M, Hors E, van den Berg F, Ponta $\mathrm{H}$, Herrlich $\mathrm{P}$, et al. A human homologue of the rat metastasis-associated variant of CD44 is expressed in colorectal carcinomas and adenomatous polyps. $f \mathrm{Cell}$ Biol 1993;120:227-33

102 Tanabe KK, Ellis LM, Saya H. Expression of CD44R1 adhesion molecule in colon carcinomas and metastases. Lancet 1993;341:725-6.

103 Ichikawa W. Positive relationship between expression of CD44 and hepatic metastases in colorectal cancer. Pathobiology 1994;62:172-9.

104 Abbasi AM, Chester KA, Talbot IC, Macpherson AS, Boxer G, Forbes A, et al. CD44 is associated with proliferation in normal and neoplastic human colorectal epithelial cells. Eur f Cancer 1993;29A: 1995-2002.

105 Mulder JW, Kruyt PM, Sewnath M, Oosting J, Seldenrijk CA, Weidema WF, et al. Colorectal cancer prognosis and 1994;344:1470-2.

106 Finke LH, Terpe HJ, Zorb C, Haensch W, Schlag PM Colorectal cancer prognosis and expression of exon-v6 containing CD44 proteins. Lancet 1995;345:583.
107 Sugino T, Gorham H, Yoshida K, Bolodeoku J, Nargund $\mathrm{V}$, Cranston D, et al. Progressive loss of CD44 gene expression in invasive bladder cancer. Am F Pathol 1996;149:873 82 .

108 Takeuchi K, Yamaguchi A, Urano T, Goi T, Nakagawara $\mathrm{G}$, Shiku H. Expression of CD44 variant exons $8-10$ in colorectal cancer and its relationship to metastasis. $f_{p n} \mathfrak{f}$ Cancer Res 1995;86:292-7.

109 Tanabe KK, Stamenkovic I, Cutler M, Takahashi K Restoration of $\mathrm{CD} 44 \mathrm{H}$ expression in colon carcinomas reduces tumorigenicity. Ann Surg 1995;222:493-501.

110 Rodriguez C, Monges G, Rouanet P, Dutrillaux B, Lefrancois D, Theillet C. CD44 expression patterns in breast and colon tumors: a PCR-based study of splice variants. Int 7 Cancer 1995;64:347-54.

111 Gorham H, Sugino T, Woodman AC, Tarin D, Cellular distribution of $\mathrm{CD} 44$ gene transcripts in colorectal carcinomas and in normal colonic mucosa. I Clin Pathol 1996;49:482-8

112 Gorham H, Sugino T, Bolodeoku J, Yoshida K, Goodison $\mathrm{S}$, Tarin D. Distribution of CD44 messenger RNA in archival paraffin wax embedded tumours and normal tissues viewed by in situ hybridisation. I Clin Pathol: $M_{0}$ l Pathol 1996;49:M147-50.

113 Yoshida K, Bolodeoku J, Sugino T, Goodison S, Matsumura $\mathrm{Y}$, Warren BF, et al. Abnormal retention of intron 9 in CD44 gene transcripts in human gastrointestinal tumors. Cancer Res 1995;55:4273-7.

114 Matsumura Y, Sugiyama M, Matsumura S, Hayle AJ, Robinson P, Smith JC, et al. Unusual retention of introns in CD44 gene transcripts in bladder cancer provides new diagnostic and clinical oncological opportunities. F Pathol 1995;177:11-20.

115 Higashikawa $\mathrm{K}$, Yokozaki $\mathrm{H}, \mathrm{Ue} \mathrm{T}$, Taniyama K, Ishikawa $\mathrm{T}$, Tarin $\mathrm{D}$, et al. Evaluation of CD 44 transcription variants
in human digestive tract carcinomas and normal tissues. $I n t$ in human digestive tract

116 Yoshida K, Sugino T, Bolodeoku J, Warren BF, Goodison $\mathrm{S}$, Woodman A, et al. Detection of exfoliated carcinoma cells in colonic luminal washings by identification of deranged patterns of expression of the CD44 gene. 7 Clin Pathol 1996;49:300-5.

117 Takahashi K, Stamenkovic I, Cutler M, Saya H, Tanabe $\mathrm{KK}$, et al. CD 44 hyaluronate binding influences growth kinetics and tumorigenicity of human colon carcinomas. Oncogene 1995;11:2223-32.

118 Miwa T, Watanabe A, Yamada Y, Shino Y, Yamada T, Yamashita J, et al. Progression in gastric carcinoma relative to the ratio of CD44 epithelial variant transcript to CD44 hematopoietic variant transcript. Cancer 1996;77:25-9.

119 Naitoh H, Yazawa S, Asao T, Nakajima T, Nakamura J, Takenoshita S, et al. The recognition of cancer-associated fucosylated antigens in colorectal cancer by a novel monoclonal antibody, YB-2. Sirr Today 1994;24:382-4.

120 Yamaguchi A, Saito M, Goi T, Iida A, Takeuchi K, Hirose $\mathrm{K}$, et al. Expression of CD44 variant exons 8-10 in gastric cancer. Fpn F Cancer Res 1995;86:11 66-71.

121 Dämmrich J, Vollmers HP, Heider KH, Müller-Hermelink HK. Importance of different CD44v6 expression in human gastric intestinal and diffuse type cancers for metastatic lymphogenic spreading. 7 Mol Med 1995;73:395-401.

122 Figge J, del Rosario AD, Gerasimov G, Dedov I, Bronstein $\mathrm{M}$, Troshina K, et al. Preferential expression of the cell adhesion molecule CD44 in papillary thyroid carcinoma. Exp Mol Pathol 1994;61:203-11.

123 Friedrichs K, Franke F, Lisboa BW, Kügler G, Gille I, Terpe HJ, et al. CD44 isoforms correlate with cellular differentiation but not with prognosis in human breast cancer. Cancer Res 1995;55:5424-33.

124 Kaufmann M, Heider KH, Sinn HP, von Minckwitz G, Ponta H, Herrlich P. CD44 variant exon epitopes in primary breast cancer and length of survival. Lancet 1995; 345:615-19.

125 Sinn HP, Heider KH, Skroch-Angel P, von Minckwitz G, Kaufmann M, Herrlich P, et al. Human mammary carcinomas express homologues of rat metastasis-associated variants of CD44. Breast Cancer Res Treat 1995;36:307-13.

126 Rall CJ, Rustgi AK. CD44 isoform expression in primary and metastatic pancreatic adenocarcinoma. Cancer Res 1995;55:1831-5.

127 Takada M, Yamamoto M, Saitoh Y. The significance of CD44 in human pancreatic cancer: I. High expression of CD 44 in human pancreatic adenocarcinoma. Pancreas 1994;9:748-52.

128 Takada M, Yamamoto M, Saitoh Y. The significance of CD44 in human pancreatic cancer: II. The role of CD44 in human pancreatic adenocarcinoma invasion. Pancreas 1994;9:753-7.

129 Fujita N, Yaegashi N, Ide Y, Sato S, Nakamura M, Ishiwata $I$, et al. Expression of CD44 in normal human versus tumor endometrial tissues: possible implication of reduced expression of CD44 in lymph-vascular space involvement of cancer cells. Cancer Res 1994;54:3922-8.

130 Kainz C, Kohlberger P, Tempfer C, Sliutz G, Gitsch G, Reinthaller A, et al. Prognostic value of CD44 splice variants in human stage III cervical cancer. Eur $\mathcal{F}$ Cancer 1995;31 A: 1706-9

131 Dall $\mathrm{P}$ Heider $\mathrm{KH}$, Hekele A, von Minckwitz G, Kaufmann $M$, Ponta $\mathrm{H}$, et al. Surface protein expression and messenger RNA-splicing analysis of CD44 in uterine cervical cancer and normal cervical epithelium. Cancer Res $1994 ; 54: 3337-41$

132 Uhl-Steidl M, Muller-Holzner E, Zeimet AG, Adolf GR, Daxenbichler G, Marth C, et al. Prognostic value of CD44 
splice variant expression in ovarian cancer. Oncology 1995; 52:400-6.

133 Brooks L, Niedobitek G, Agathanggelou A, Farrell PJ. The expression of variant CD44 in nasopharyngeal carcinoma is unrelated to expression of LMP-1. Am $f$ Pathol is unrelated to exp

134 Penno MB, August JT, Baylin SB, Mabry M, Linnoila RI, Lee VS, et al. Expression of CD44 in human lung tumors. Cancer Res 1994;54:1381-7.

135 Chaudhry A, Gobl A, Eriksson B, Skogseid B, Oberg K. Different splice variants of CD44 are expressed in gastrinomas but not in other subtypes of endocrine pancreatic tumors. Cancer Res 1994;54:981-6.

136 Clarke MR, Landernau RJ, Resnick NM, Crowley R, Dougherty GJ, Cooper DL, et al. Prognostic significance of CD44 expression in adenocarcinoma of the lung. 7 Clin Pathol: Mol Pathol 1995;48:M200-4.

137 Cannistra SA, Kansas GS, Niloff J, DeFranzo B, Kim Y, Ottensmeier C. Binding of ovarian cancer cells to peritoneal mesothelium in vitro is partly mediated by CD44H. Cancer Res 1993;53:3830-8.

138 Terpe HJ, Storkel S, Zimmer U, Anquez V, Fischer C, Pantel K, et al. Expression of CD44 isoforms in renal cell tumors-positive correlation to tumor differentiation $A m \mathcal{F}$ Pathol 1996;148:453-63.

139 Shtivelman E, Bishop JM. Expression of CD44 is repressed in neuroblastoma cells. Mol Cell Biol 1991;11: 5446-53.
140 Gross N, Beretta C, Peruisseau G, Jackson D, Simmons D, Beck D. CD44H expression by human neuroblastoma cells: relation to MYCN amplification and lineage differentiation. Cancer Res 1994;54:4238-42.

141 Combaret V, Coll JL, Favrot MC. Expression of integrin and CD44 adhesion molecules on neuroblastoma: the relation to tumor aggressiveness and embryonic neural-crest differentiation. Invasion Metastasis 1994;14:156-63

142 Combaret V, Lasset C, Frappaz D, Bouvier R, Thiesse P, Rebillard AC, et al. Evaluation of CD44 prognostic value in neuroblastoma: comparison with the other prognostic factors. Eur $\mathcal{F}$ Cancer 1995;31A:545-9.

143 Ariza A, Lopez D, Mate JL, Isamat M, Musulen E, Pujol M, et al. Role of CD44 in the invasiveness of glioblastoma multiforme and the noninvasiveness of meningioma - an immunohistochemistry study. Hum Pathol 1995;26:1144-7.

144 Eibl RH, Pietsch T, Moll J, Skroch-Angel P, Heider KH, Vonammon K, et al. Expression of variant CD44 epitopes in human astrocytic brain tumors. $\mathcal{F}$ Neurooncol $1995 ; 26$ : $165-70$

145 Kaaijk P, Troost D, Morsink F, Keehnen RMJ, Leenstra S, Bosch DA, et al. Expression of CD44 splice variants in human primary brain tumors. 7 Neurooncol 1995;26:18590.

146 Sherman L, Skroch-Angel P, Moll J, Schwechheimer K, Ponta H, Herrlich P, et al. Schwann cell tumors expres characteristic patterns of CD44 splice variants. $¥$ Neurooncol 1995;26:171-84. 